\title{
ANALISIS PEMANFAATAN RUANG TERBUKA HIJAU PADA PEMUKIMAN PADAT DI KECAMATAN RAPPOCINI KOTA MAKASSAR
}

\author{
Siti Fuadillah A. Amin ${ }^{1}$ \\ Universitas Muhammadiyah Makassar (sfuadillah@gmail.com ${ }^{1}$;
}

\begin{abstract}
ABSTRAK
Ketersediaan Ruang Terbuka Hijau khususnya pada wilayah perkotaan sangat penting mengingat besarnya manfaat yang diperoleh dari keberadaan RTH tersebut. Untuk meningkatkan kualitas dan kuantitas Ruang Terbuka Hijau (RTH), khususnya pada kawasan permukiman padat, Pemanfaatan RTH menjadi hal yang menarik untuk diteliti karena kebanyakan RTH sudah bergeser dari fungsinya. Penelitian ini bertujuan mengetahuai apakah luas dan rencana pengembangan Ruang Terbuka Hijau sesuai aturan, dan mengetahui alternatif kebijakan yang digunakan dalam meningkatkan pengelolaan Ruang Terbuka Hijau. Penelitian ini juga dilakukan identifikasi Ruang Terbuka Hijau yang telah ada di wilayah pemukiman padat di Kecamatan Rappocini. Kecamatan Rappocini membutuhkan RTH adalah 30\% dari luas wilayah yaitu 276.9 ha dan untuk Kelurahan Ballaparang dan Bonto Makkio yang berada di Kelurahan Rappocini yaitu sebesar 15,36 ha untuk Kelurahan Ballaparang dan 6 ha untuk Kelurahan Bontomakkio Pengembangan Ruang Terbuka Hijau (RTH) pada permukiman padat di kedua Kelurahan yang ada di Kecamatan Rappocini Kota Makassar terdapat peningkatan dilihat dari jenis RTH yang sudah ada sekarang. Terdapat RTH public seperti taman lingkungan dan juga RTH privat seperti RTH pekarangan dan taman atap.
\end{abstract}

Kata Kunci : Ketersediaan, Ruang Terbuka Hijau, Jenis RTH

\section{PENDAHULUAN Latar Belakang}

Pembangunan di wilayah perkotaan terus meningkat seiring dengan bertambahnya jumlah penduduk dan kebutuhan masyarakat akan sarana dan prasarana kota. hal ini umumnya merugikan keberadaan Ruang Terbuka Hijau (RTH) yang sering dianggap sebagai lahan cadangan dan tidak ekonomis. Ketersediaan Ruang Terbuka Hijau khususnya pada wilayah perkotaan sangat penting mengingat besarnya manfaat yang diperoleh dari keberadaan RTH tersebut.

Ruang terbuka hijau merupakan salah satu komponen yang tingkat ketersediannya baik secara kualitas maupun kuantitas harus selalu diperhitungkan dalam proses perencanaan kota (Roswidyatmoko Dwihatmojo, 2013). Peraturan yang memuat RTH adalah Keputusan Menteri atau Peraturan Menteri, antara lain instruksi Mendagri No. 14 Tahun 1988 tentang Penataan Ruang Terbuka Hijau (RTH) di perkotaan, Peraturan Menteri Dalam Negeri No. 1 Tahun 2007 tentang Penataan Ruang Terbuka Hijau(RTH),serta beberapa Peraturan Perundangan lainnya yang keseluruhannya memuat fungsi, kriteria, jenis, pengelolaan, standar luas Ruang Terbuka Hijau (RTH).

Kecamatan Rappocini merupakan salah satu dari 14 Kecamatan di Kota Makassar. Terdiri dari 11 kelurahan dengan Jumlah Penduduk sekitar 190.539 Jiwa pada bulan Juli tahun 2016. Penggunaan lahan di kecamatan ini hampir seluruhnya diperuntukkan sebagai kawasan pemukiman. Persentase penggunaan lahan sebagai kawasan pemukiman sangat besar hampir
$65 \%$. Untuk itu diperlukan penelitian yang detail terkait Analisis pemanfaatan ruang terbuka pada pemukiman padat di Kecamatan Rappocini Kota

\section{TINJAUAN PUSTAKA}

\section{Pengertian Ruang Terbuka Hijau}

Ruang terbuka hijau adalah area memanjang/jalur dan/atau mengelompok, yang penggunaannya lebih bersifat terbuka, tempat tumbuh tanaman, baik yang tumbuh secara alamiah maupun yang sengaja ditanam.

\section{Fungsi, manfaat dan Jenis RTH}

Fungsi dan manfaat serta Elemen Pengisi Ruang Terbuka Hijau (RTH) Ruang Terbuka Hijau, baik Ruang Terbuka Hijau Publik maupun Ruang Terbuka Hijau Privat, memiliki fungsi utama (intrinsik) yaitu fungsi ekologis, dan fungsi tambahan (ekstrinsik) yaitu fungsi arsitektural, sosial, dan fungsi ekonomi.

Dalam permendagri No. 1 tahun 2007 disebutkan fungsidan manfaat Ruang Terbuka Hijau (RTH) kota yaitu:Fungsi Ruang Terbuka Hijau (RTH) kawasan perkotaan adalah: Pengaman keberadaan kawasan lindung perkotaan; Pengendali pencemaran dan kerusakan tanah, air, dan udara; Tempat perlindungan plasma nutfah dan keanekaragaman hayati; Pengendali tata air; Sarana estetika kota.

Sementara manfaat Ruang Terbuka Hijau (RTH) kawasan perkotaan adalah: 1) Sarana untuk mencerminkan identitas daerah; 2) Saranapenelitian; 3) Sarana rekreasi aktif dan pasif serta interaksi sosial;4) Mengingkatkan nilai ekonomi lahan perkotaan; 5) Menumbuhkan 
rasabangga dan meningkatkan prestasi daerah (Permendagri No. 1 Tahun 2007).

Jenis ruang terbuka hijau menurut Permendagri Nomor 1 Tahun 2007, jenis Ruang Terbuka Hijau Kawasan Perkotaan terdiri dari : Taman kota;Taman wisata alam;Taman rekreasi; Taman lingkungan perumahan dan permukiman; Taman lingkungan perkantoran dan gedung komersial; Taman hutan raya; Hutan kota; Hutan lindung; Bentang alam (seperti gunung, bukit, lereng dan lembah); Cagar alam; Kebun raya; Kebun binatang; Pemakaman umum; Lapangan olahraga; Lapangan upacara; Parkir terbuka; Lahan pertanian perkotaan; Jalur dibawah tegangan tinggi (SUTT dan SUTET); Sempadan (sungai, pantai, bangunan, situ dan rawa); Jalur pengaman (jalan, median jalan, rel kereta api, pipa gas dan pedestrian); Kawasan dan jalur hijau; Daerah penyangga (buffer zone) lapangan udara; dan Taman atap (garden roof).

\section{Perencanaan Ruang Terbuka Hijau di Kota Makassar}

Pemerintah Kota Makassar mengeluarkan reguasi mengenai penataan ruang untuk mengarahkan pembangunan di Kota Makassar yang tertuang dalam Peraturan Daerah Kota Makassar Nomor 4 tahun 2015 tentang Rencana Tata Ruang Wilayah Kota Makassar Tahun 2015 2034, sebagai upaya pemanfaatan ruang wilayah secara berdaya guna, berhasil guna, serasi, selaras, dan berkelanjutan terhadap peningkatan pembangunan di Kota Makassar.Penataan ruang di Kota Makassar ditetapkan melalui kebijakan dan strategis penataan ruang wilayah yang meliputi pengembangan struktur kota, Pengembangan pola ruang kota, dan pengembangan kawasan strategis kota.

Pengembangan struktur kota dalam penataan ruang di Kota Makassar dilaksanakan melalui strategi pengembangan kawasan lindung dan budi daya melalui peningkatan derajat kualitas hijau ruang wilayah yang diantaranya dengan menetapkan penyediaan ruang terbuka hijau. Regulasi ini lah yang di ikuti semua kecamatan di Kota Makassar salah satunya Kecamatan Rappocini yang memilik 11 Kelurahan. Kecamatan Rappocini merupakan salah satu dari 14 Kecamatan di Kota Makassar

\section{METODE PENELITIAN Lokasi dan Waktu Penelitian}

Metode penelitian yang digunakan adalah metode penelitian kuantitatif dengan melakukan observasi lapangan. Lokasi penelitian di Kecamatan Rappocini dan beberapa Kelurahan yang berada di kecamatan Rappocini Kota Makassar dengan waktu penelitian empat (4) bulan. Batasan lokasi penelitian adalah pada kawasan permukiman padat.

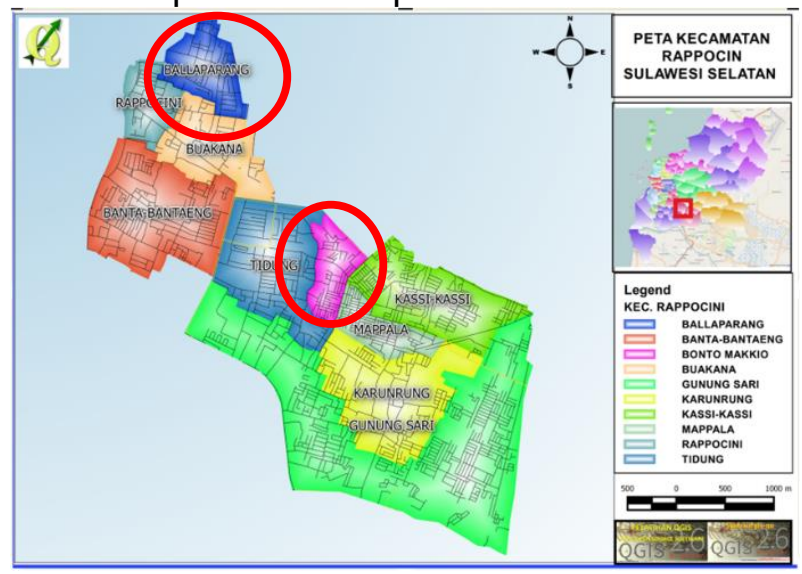

(Sumber : www.google.com)

Gambar 1. Peta Kecamatan Rappocini Kota Makassar

\section{Model Analisis}

Adapun model analisis menggunakan parameter yang dapat dilihat pada table :

Tabel 1. Kebutuhan Ruang Terbuka hijau

\begin{tabular}{|c|c|c|c|}
\hline Kelurahan & Luas (Ha) & $\begin{array}{l}\text { Standar } \\
\text { Luasan } \\
\text { RTH }\end{array}$ & $\begin{array}{l}\text { Kebutuhan } \\
\text { RTH }\end{array}$ \\
\hline $\begin{array}{l}\text { Mengambil } \\
\text { sampel } \\
\text { beberapa } \\
\text { kelurahan }\end{array}$ & $\begin{array}{l}\text { Luas tiap- } \\
\text { tiap } \\
\text { Kelurahan } \\
\text { yang } \\
\text { digunakan } \\
\text { sebagai } \\
\text { sampel }\end{array}$ & $\begin{array}{l}20-30 \% \\
\text { dari luas } \\
\text { wilayah }\end{array}$ & $\begin{array}{l}\text { Analisi } \\
\text { kebutuhan } \\
\text { sesuai } \\
\text { standar RTH }\end{array}$ \\
\hline
\end{tabular}

Tabel 2. Jenis Ruang Terbuka Hijau

\begin{tabular}{llll}
\hline No & Kelurahan & $\begin{array}{l}\text { Jenis- Jenis } \\
\text { RTH }\end{array}$ & Dok. \\
\hline 1 & $\begin{array}{l}\text { Mengambil } \\
\text { sampel } \\
\text { beberapa } \\
\text { kelurahan }\end{array}$ & $\ldots$ & $\ldots .$. \\
\hline
\end{tabular}

Untuk memperoleh data maka tehnik pengumpulan data yang digunakan dengan cara Observasi/pengamatan, wawancara dan dokumentasi.

\section{HASIL DAN PEMBAHASAN}

Lokasi terletak di Kecamatan Rappocini dan mengambil sampel 2 Kelurahan di Kecamatan Rappocini Kota Makassar yaitu Kelurahan Ballaparang dan Kelurahan Bontomakkio. Dimana Luas Wilayah Kecamatan Rappocini sebesar 9,23 $\mathrm{Km}^{2}$ dan Presentasi terhadap Luas wilayah kota adalah 5,25\%

\section{Kebutuhan Ruang Terbuka Hijau}


Melihat Iuasan Kecamatan Rappocini yaitu $9,23 \mathrm{~km}^{2}$ atau 923 ha maka Kecamatan Rappocini membutuhkan $\mathrm{RTH}$ adalah $30 \%$ dari luas wilayah yaitu 276.9 ha.

Tabel 3. Kebutuhan Ruang Terbuka hijau

\begin{tabular}{|c|c|c|c|c|}
\hline No. & $\begin{array}{l}\text { Kelurah } \\
\text { an }\end{array}$ & $\begin{array}{l}\text { Lua } \\
\text { s } \\
\text { (Ha) }\end{array}$ & $\begin{array}{l}\text { Standa } \\
\mathbf{r} \\
\text { Luasa } \\
\text { n RTH }\end{array}$ & $\begin{array}{l}\text { Kebutuh } \\
\text { an RTH } \\
\text { (ha) }\end{array}$ \\
\hline 1 & $\begin{array}{l}\text { Ballapar } \\
\text { ang }\end{array}$ & $\begin{array}{l}51,2 \\
3\end{array}$ & $\begin{array}{l}30 \% \\
\text { dari } \\
\text { luas } \\
\text { wilayah }\end{array}$ & 15,36 \\
\hline 2 & $\begin{array}{l}\text { Bonto } \\
\text { Makkio }\end{array}$ & 20 & $\begin{array}{l}30 \% \\
\text { dari } \\
\text { luas } \\
\text { wilayah }\end{array}$ & 6 \\
\hline
\end{tabular}

Dengan melihat luasan kedua kelurahan diatas dibutuhkan RTH pada masing-masing kelurahan sebesar 15,36 ha untuk Kelurahan Ballaparang dan 6 ha untuk Kelurahan Bontomakkio. Besaran Ruang Terbuka Tersebut Terdiri dari $20 \%$ Ruang terbuka Publik dan $10 \%$ Ruang Terbuka Hijau Privat.

\section{Kelurahan Ballaparang}

Lahan yang ada di Kelurahan Balla Parang difungsikan berbeda-beda olek penduduk Kelurahan Balla Parang, sebagian besar umumnya didominasi oleh permukiman untuk lebih jelasnya akan diurai di dalam tabulasi dan grafik di bawah ini.

Tabel 4. Pola Penggunaan Lahan di Kelurahan Balla Parang

\begin{tabular}{ccc}
\hline No & $\begin{array}{c}\text { Jenis } \\
\text { Penggunaan }\end{array}$ & $\begin{array}{c}\text { Persentase } \\
\text { Luas (\%) }\end{array}$ \\
\hline 1 & Kebun & 3 \\
2 & Permukiman & 95 \\
3 & Tanah Kosong & 2 \\
\hline
\end{tabular}

Berdasarkan table pola penggunaan lahan di atas maka dapat disimpulkan bahwa sebagian besar luas lahan yang ada di Kelurahan Balla Parang digunakan untuk lokasi permukiman yaitu $95 \%$, sisanya sebesar $5 \%$ digunakan sebagai lokasi kebun dan bahkan masih ada juga yang merupakan lahan kosong. Lahan dan tanah kosong yang di kelurahan berpotensi dijadikan Ruang terbuka hijau atau ruang terbuka public.

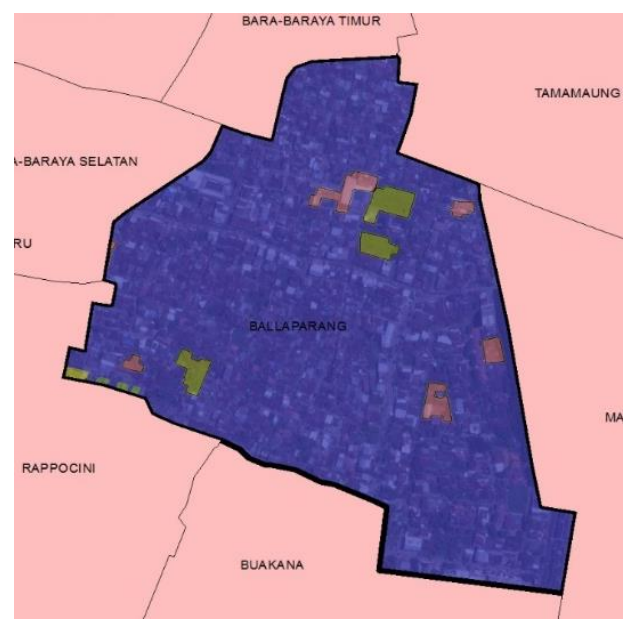

Gambar 2. Tata Guna Lahan Kelurahan Ballaparang

\section{Kelurahan Bonto Makkio}

Lahan yang ada di Kelurahan Bonto Makkio sama halnya di Kelurahan Ballaparang juga difungsikan berbeda-beda tetapi sebagian besar umumnya didominasi oleh permukiman tetapi tidak sepadat dengan yang ada diKelurahan Ballaparang.

Tabel 5. Pola Penggunaan Lahan di Kelurahan

\begin{tabular}{ccc}
\multicolumn{3}{c}{ Bonto Makkio } \\
\hline No & $\begin{array}{c}\text { Jenis } \\
\text { Penggunaan }\end{array}$ & $\begin{array}{c}\text { Persentase } \\
\text { Luas (\%) }\end{array}$ \\
\hline 1 & Kebun & 5 \\
2 & Permukiman & 83 \\
3 & Lapangan & 5 \\
4 & Tanah Kosong & 2 \\
\hline
\end{tabular}

\section{Jenis Ruang Terbuka Hijau}

Di Kelurahan BallaParang sendiri ketersediaan ruang-ruang publik ini tersedia namun tidak terlalu termanfaatkan dengan baik, begitu pula dalam hal penyediaan RTH privat yang cenderung terabaikan dalam kawasan permukiman apalagi di permukiman padat tetapi masyarakat sudah mulai peduli dengan adanya program pemerintah yang menyentuh hingga ke lorong yang merupakan pemukiman padat. Dimana Terdapat warga yang memanfaatkan pekarangan untuk bercocok tanam seperti Kol dan cabai dan juga menghijaukan jalur jalan di lorong- lorang pada pemukiman padat. Sehingga dapat dilihat dari jenis RTH yang telah ada sehingga masyarakat sudah dapat merasakan manfaatnya.

Lain halnya di Kelurahan Bonto Makkio walaupun sebagian besar wilayah nya terdiri dari pemukiman namun $\mathrm{RTH}$ pada wilayah ini dapat diterapkan bahkan ditingkatkan. Hal ini dapat 
dilihat yaitu salah satu RW pada Kelurahan ini yang mengikuti Lomba Lingkungan Bersih Sehat mengubah lahan kosong menjadi Ruang Terbuka tanpa melupakan Ruang Terbuka Hijau. Dan diwilayah ini pula setiap rumah mengembangkan RTH Privat yaitu RTH pekarangan.

Tabel 6. Jenis RTH

\begin{tabular}{lll}
\hline No & Kelurahan & Jenis- Jenis RTH \\
\hline 1. & $\begin{array}{l}\text { Kelurahan } \\
\text { Ballaparang }\end{array}$ & $\begin{array}{l}\text { a. } \\
\text { rumah pekarangan }\end{array}$ \\
& b. RTH taman atap \\
& c. RTH taman lingkungan \\
& d. RTH jalur hijau jalan \\
& e. RTH Perkantoran \\
& $\begin{array}{l}\text { Kelurahan } \\
\text { Bonto Makkio }\end{array}$ & $\begin{array}{l}\text { a. RTH pekarangan } \\
\text { rumah }\end{array}$ \\
& b. RTH Lapangan \\
& c. RTH taman atap \\
& d. RTH taman lingkungan \\
& e. RTH jalur hijau jalan \\
& f. RTH Perkantoran, dll
\end{tabular}
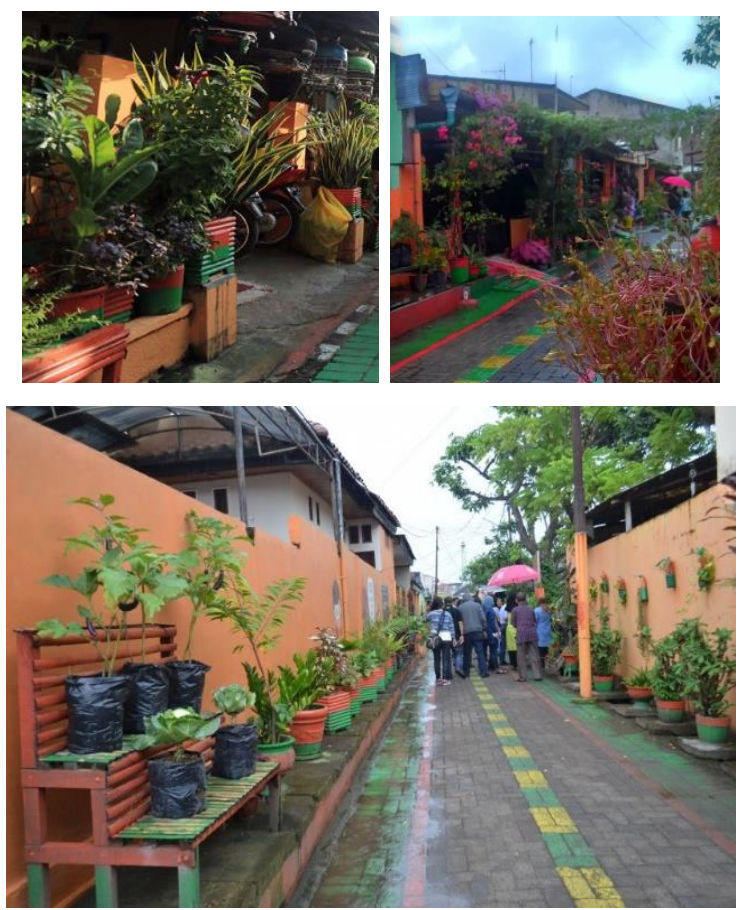
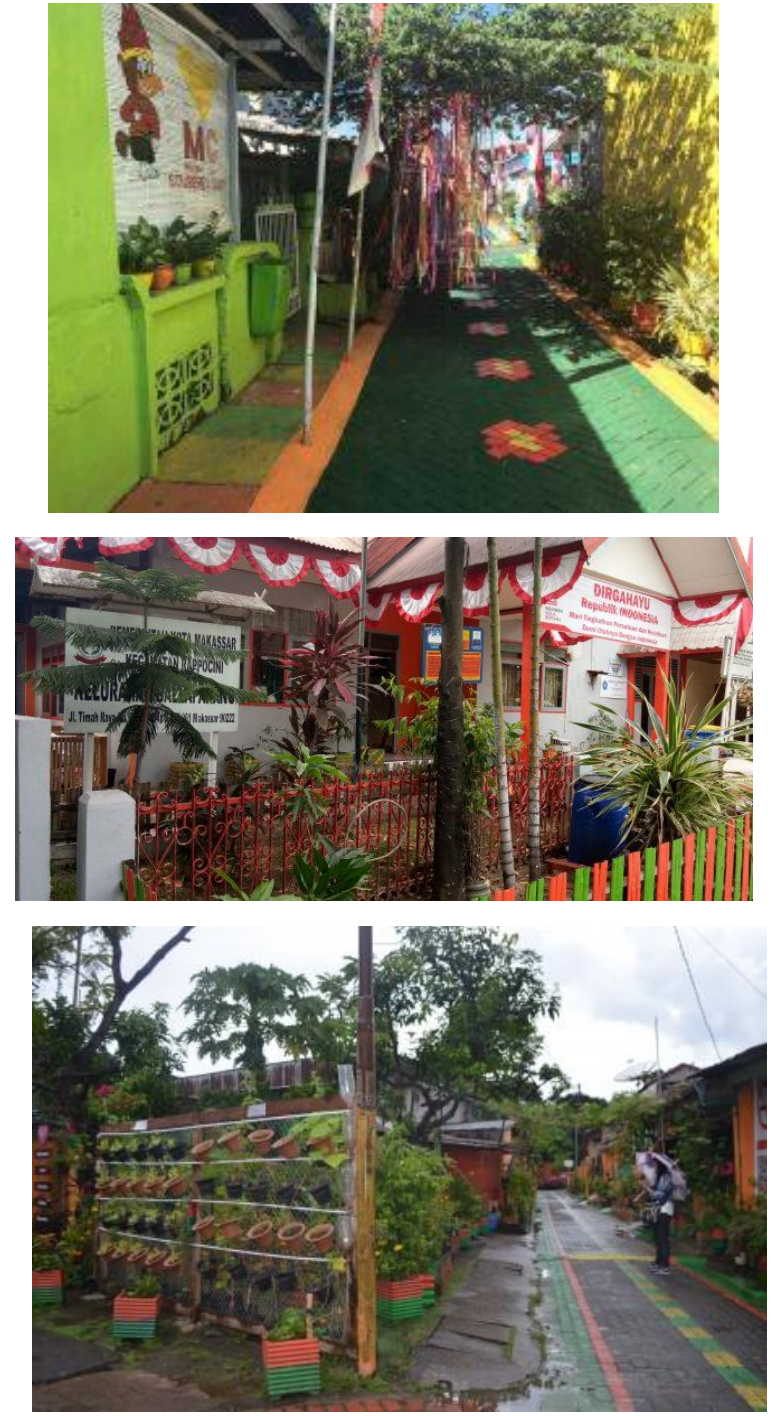

Gambar 3. Jenis jenis RTH yang ada di dua Kelurahan di Kecamatan Rappocini

\section{KESIMPULAN}

Berdasarkan hasil penelitian yang telah dilakukan mengenai Analisis Pemanfaatan Ruang Terbuka Hijau Pada Pemukiman Padat di Kecamatan Rappocini Kota Makassar maka disimpulkan bahwa : Kecamatan Rappocini membutuhkan RTH adalah $30 \%$ dari luas wilayah yaitu 276.9 ha dan untuk Kelurahan Ballaparang dan Bonto Makkio yang berada di Kelurahan Rappocini yaitu sebesar 15,36 ha untuk Kelurahan Ballaparang dan 6 ha untuk Kelurahan Bontomakkio. Besaran Ruang Terbuka Tersebut Terdiri dari $20 \%$ Ruang terbuka Publik dan $10 \%$ Ruang Terbuka Hijau Privat. Pengembangan Ruang Terbuka Hijau (RTH) pada permukiman padat di kedua Kelurahan yang ada di Kecamatan Rappocini Kota Makassar terdapat peningkatan dengan melihat keadaan dilapangan yang tidak lepas dari program pemerintah yang membuat 
partisipasi warga untuk membuat Ruang Terbuka Hijau baik public maupun privat ini meningkat. Sehingga masyarakat dapat merasakan sendiri manfaat dengan adanya Ruang Terbuka Hijau ini.

\section{SARAN}

Penelitian ini masih membutuhkan kajian lebih teranalisis terkait tingkat kepadatan bangunan kaitannya dengan Ruang Terbuka Hijau .Diperlukan arahan kebijakan terutama dari instansi terkait mengenai Ruang Terbuka Hijau.

\section{DAFTAR PUSTAKA}

Badan Pusat Statistik. 2015. Makassar Dalam Angka. November. BPS Kota Makassar. Makassar.

Dokumen RPLP (Rencana Penataan Lingkungan Permukiman), 2016. Program KOTAKU (Kota Tanpa Kumuh). Kota Makassar

Intruksi Menteri Dalam Negeri Nomor 14 Tahun 1988 tentang Penataan Ruang Terbuka Hijau (RTH) di wilayah Perkotaan

Peraturan Menteri Pekerjaan Umum Nomor : 05/PRT/M/2008 Tentang Pedoman Penyediaan dan

Pemanfaatan Ruang Terbuka Hijau di Kawasan Perkotaan

Permendagri No. 1 tahun 2007

Undang-undang No. 26 Tahun 2007 tentang Penataan Ruang. 